\title{
Pronunciamiento sobre la conveniencia que el Perú ofrezca a la comunidad internacional ser sede de uno de los centros de producción de la vacuna contra el
}

\section{Covid-19}

\section{Pronunciamiento SPDI $N^{\circ}$ 004-2020}

La actual pandemia de Covid-19 representa una grave amenaza al derecho humano a la salud, y siendo ésta un bien público global, su protección requiere de la acción solidaria de toda la humanidad.

Actualmente existen varios emprendimientos de investigación científica orientados a producir una vacuna contra el Covid-19, algunos de los cuales prometen ser exitosos. Descubierta la vacuna, el reto de toda la comunidad global será producirla muy masivamente y distribuirla, para que todas las personas sin discriminación alguna tengan acceso a ella. Esto implicará implementar centros de producción en diversos países.

El Perú tiene limitadas capacidades de investigación científica, lo cual hace improbable el descubrimiento de la vacuna contra el Covid-19 con recursos nacionales. Pero resulta de estratégica importancia que nuestro país contribuya a garantizar la aceleradísima y masiva producción de tal vacuna una vez sea descubierta, para compartirla con el resto de la comunidad internacional, y en particular dentro de Latinoamérica y en nuestro propio país.

Como Estado Miembro de las Naciones Unidas, el Perú tiene la obligación de contribuir al logro de los propósitos de esta máxima organización internacional, y de modo especial, en esta crítica circunstancia, el de "[r]ealizar la cooperación internacional en la solución de problemas internacionales de carácter económico, social, cultural o humanitario, y en el desarrollo y estímulo del respeto a los derechos humanos [...]", previsto en el artículo $1.3^{\circ}$ de la Carta de las Naciones Unidas.

En base a las consideraciones precedentes, la Sociedad Peruana de Derecho Internacional considera pertinente solicitar a las autoridades de nuestro Gobierno que formalmente ofrezcan al resto de la comunidad internacional plenas facilidades para que en el Perú se instale uno de los centros de producción de la vacuna contra el Covid-19, una vez sea esta descubierta por cualquiera de los emprendimientos de investigación científica en curso, 
garantizando nuestro país plenas facilidades para el efecto. Como parte de este ofrecimiento de cooperación global, el Perú debiera donar los terrenos para la edificación de tal centro de producción, otorgarle un régimen legal especial, y efectuar un aporte económico. Adicionalmente, nuestro Estado debiera expresar su compromiso de facilitar todas las acciones necesarias para lograr la inmediata y equitativa distribución internacional de las dosis de vacuna que tal centro de producción elabore.

Este ofrecimiento, además de representar una expresión tangible de la vocación de cooperación global del Perú, aceleraría la disponibilidad de la referida vacuna dentro de nuestro propio país.

Lima, 22 de mayo de 2020 